\title{
In memory of Professor Jan Mazurkiewicz in the 70th anniversary of his death
}

\author{
Wspomnienie o Prof. Janie Mazurkiewiczu w 70-tą rocznicę śmierci
}

\author{
Aneta Perzyńska - Starkiewicz A,B,E,F
}

II Department of Psychiatry and Psychiatry Rehabilitation, Medical University of Lublin

\begin{abstract}
This article reminisces about the life and career of Jan Mazurkiewicz, one of the most outstanding Polish psychiatrists - the author of Psychophysiological Theory, an original conception of mental disease based on the theory of evolution and dissolution of the nervous system developed by the Englishneurologist John Hughlings Jackson. Professor Jan Mazurkiewicz was an active organizer of psychiatric care. He was co-founder and director of hospitals in Kochanówka and Kobierzyn. He held the rank of Associate Professor at the John Casimir University in Lviv and the position of Professor at the Jagiellonian University in Cracow. From 1919 unt il his death in 1947, Professor Jan Mazurkiewicz was the head of the Department of Psychiatry at the University of Warsaw. For twenty three years, starting from 1924, he was the president of the Polish Psychiatric Association. The Mazurkiewicz's Psychopath ological Theory provides a natural model of development of the highest psychic functions.Damage to a higher evolutionary level of the nervous system leads to the activation of the previously suppressed lower levels, transformed by the pathogen into psychopathological symptoms.Mazurkiewicz's scientific thought was adopted and developed by his student andthen, collaborator, Professor MieczysławKaczyński,who was later to become the head of the Department of Psychiatry in Lublin. This work discusses the research conducted at Lublin's Department of Psychiatry which expands on Mazurkiewicz's theory
\end{abstract}

Keywords: Jan Mazurkiewicz, psychophysiological theory, dissolution

\section{Streszczenie}

W pracy przypomniano sylwetkę profesora Jana Mazurkiewicza, jednego z najwybitniejszych polskich psychiatrów - twórcy oryginalnej teorii psychofizjologicznej, opartej na ewolucyjno -dyssolucyjnej koncepcji angielskiego neurologa J.H.Jacksona. Profesor Jan Mazurkiewicz był aktywnym organizatorem opieki psychiatrycznej. Był współtwórcą i dyrektorem szpitali w Kochanówce i Kobierzynie. Pracował na stanowiskach docenta Uniwersytetu Jana Kazimierza we Lwowie oraz profesora Uniwersytetu Jagiellońskiego w Krakowie. Od 1919 roku, aż do śmierci w roku 1947, prof. Jan Mazurkiewicz pełnił funkcję kierownika Kliniki Psychiatrii Uniwersytetu Warszawskiego. Od 1924 roku - przez 23 lata - pełnił funkcję prezesa Polskiego Towarzystwa Psychiatrycznego. Stworzona przez prof. J. Mazurkiewicza teoria psychofizjologiczna, tworzy naturalny, przyrodniczy model rozwoju najwyższych czynności psychicznych. Uszkodzenie wyższego piętra ewolucyjnego skutkuje uwolnieniem się psychizmów niższych, przekształconych przez czynnik chorobotwórczy do formy objawów psychopatologicznych. Kontynuatorem myśli naukowej prof. J. Mazurkiewicza był jego uczeń a następnie współpracownik, późniejszy kierownik Kliniki Psychiatrii w Lublinie prof. Mieczysław Kaczyński. W pracy wskazano, na rozwijające koncepcję Mazurkiewicza wyniki badań, prowadzonych w lubelskiej Klinice Psychiatrii.

Słowa kluczowe: Jan Mazurkiewicz , teoria psychofizjologiczna, dyssolucja

\section{The life and career of Professor Jan Mazurkiewicz}

Professor Jan Mazurkiewicz was born on July 12, 1871. Having received the degree of Doctor of Medicine in 1896, he enrolled ona postgraduate programme at the University in Graz and then in Paris. His first publications appeared in 1900 in Graz and were devoted to the study of the anatomical and physiological foundations of mental life, which Mazurkiewicz believed was the only legitimate direction for scientific development of psychiatry.

His broad knowledge of the literature of the subject and his own original clinical thought bore fruit in his monographs, devotedto, among others, the physiological theory of emotions and integration of higher-order nervous activities. Subsequent publications formed the foundations of the emerging psychophysiological theory and became the basis on which Mazurkiewicz was granted the degree of habilitated doctor in 1909, and 10 years later, atitle of the Professor. In parallel with scientific activity, Professor Mazurkiewicz was actively involved in medical practice. Among others, he organized work in hospitals in Kochanówka and Kobierzyn. He presided over the ministerial Department of Health. In the years 1909-1918, he held the rank of Associate Professor at the John Casimir University in Lviv. In January 1919, he was granted the 
title of Professor of Jagiellonian University in Cracow. From October 1919 until his death in 1947, Professor Mazurkiewicz was in charge of the Clinic of Psychiatry of the University of Warsaw, holding the position of Dean and later Rector (President) of his home university. During the Nazi occupation, he was a lecturer on the secretteaching courses for medical doctors. For 23 years, starting from 1924, he was the president of the Polish Psychiatric Association [1,2,3].

During the German occupation, Mazurkiewicz completed a two-volume work devoted to the evolution of higher mental activities (volume one) [4], and dissolution, the reverse of evolution, which unveils the clinical picture of disease(volume two) [5].

\section{The Psychophysiological Theory}

The English neurologist John Hughlings Jackson, referred to by Mazurkiewicz as "the father of the world neurology", assumed that the basic function of the nervous system, which should be viewed from an evolutionary point of view, was the accumulation and transfer of energy. Jackson considered the individual stages of the nervous system evolution to represent four levels of dynamic activity, claiming that the evolutionary process proceeded from the simplest automatic functions to more complex, but,at the same time,poorly organized, controlled functions located in higher brain areas. He believed that this was the reason why the highest evolutionary areas were more susceptible to damage. Dissolution (the progressing disease) damages parts of a higher level (never destroying it fully), what results in negative symptoms. The effect of this process is the activation of the heretofore suppressed lower level, which, having undergone a pathological change, manifests in the form of the positive symptoms. Professor Mazurkiewicz transplanted Jackson's evolution-dissolution-based approach into psychiatry, assuming that there existed four developmental levels of mental activity.

Mazurkiewicz's psychopathological theory is based on an analysis of the phylogenetic development of the biological foundations of higher-order nervous activities.It is recapitulated in a dozen or so years in human ontogenesis and provides a natural model of the development of the highest psychic functions. With its view of a disease as a consequence of damage to the higher evolutionary levels of the nervous system resulting in the activation of the previously suppressed lower levels transformed by the pathogen into psychopathological symptoms, this theory is considered by many psychiatrists to constitute a philosophy of psychiatry. Professor Mazurkiewicz described the mental functions characteristic forthe individual evolutionary levels. The first level is dominated by inherited instincts (impulses, unconditional reflex- es) which control the functions of an infant up to 2-3 months of age. From about three months to two years of age, a child develops reflexively conditioned mechanisms that take control over the instincts. The totalitarian thought of postwar Poland, which was based on the distorted principles of Pavlov's theory, saw the development of human psychic functions as being limited to the level of conditional reflexes. The PsychophysiologicalTheory distinguished two further stages of development: the period of intrapsychic, pre-logical activity (3-7 years of age) and the period which lasts from about seven years of age until maturity and is characterized by the formation of, as Mazurkiewicz himself put it, "frontally linked abstract processes ofintentional, causal-logical activity". Mieczyslaw Kaczyński, Mazurkiewicz's student and then, collaborator, noted that this highest evolutionary level in man played an "inhibiting, organizing, unifying and controlling" role [6,7] with respect to the lower evolutionary levels.A pathogen first damages thephylogenetically youngest structures, i.e. those which are the best organized but at the same time the weakest, the least resistant.

\section{Types of dissolution}

Mazurkiewicz distinguished the following types of mental dissolution disorders: psychoneurotic ('intra-level') dissociation, slow dissociation or dissociation proper(schizophrenia), and rapid dissociation ('delirium' - psychosis with impaired consciousness). According to the Psychophysiological Theory, the affective diseases do not belong to the category of dissociation disorders because the lower-level symptoms manifesting in the former have a different, 'secondary' pathogenesis. A similar case is the regression observed in dementia which arises secondary to "deterioration of the anatomic substrate". Also other psychoses, such as paraphrenia and paranoia, do not display the features of level-by-leveldissolution. Professor Mazurkiewicz referred to them as "acute or chronic pre-logical psychoses".

The creator of psychophysiological theory died on October 31, 1947.

\section{Elaboration of the Psychophysiological Theory in the Lublin Clinic of Psychiatry}

A student of Mazurkiewicz and then his associate in the Warsaw Psychiatry Clinic, Professor Kaczyński, continued the research started by his mentor. After becoming in January 1949 the head of the Lublin Department of Psychiatry, he mainly studied slow dissolution (dissolution proper), i.e. schizophrenia. Particularly important for clinical practice is his description of the changes in characterological traits manifesting in early stages of the disease [8]. Research conducted by his successor, Professor Masiak, yielded a description of the "dissolutional balance" characterizing the clinical course of schizophrenia [9]. In turn, 
a thirty-year longitudinal study conducted by Professor Perzyński, who observed the same group of patients with schizophrenia during the successive periods of hospitalization and remission, resulted in the description of a 'dissolutional cross' characteristic of paranoid schizophrenia and the 'directions of dissolution' and a 'dissolution map' - tools that are of use in the diagnosis and prognosis of schizophrenia $[10,11,12]$.

\section{Conclusion}

Professor Mieczysław Kaczyński in his valediction for his master, emphasized the importance of the idea of evolution-dissolution of psychic activity, which he called
Mazurkiewicz's "magnum opus", saying the following: "I think that whenever we reminisce about this Scholar, we should, out of scientific, professional and patriotic obligation, mention his theory. This is because the dissolution approach facilitates understanding of the pathogenesis of psychiatric symptoms on the contemporary level of knowledge. This theory represents the original Polish thought, justifying the claim that there exists the Polish scientific psychiatry - which, due to its high standards, has the right to enter the international arena." [13]. It seems that these words, though written 70 years ago, are still valid.

\section{Sylwetka Profesora Jana Mazurkiewicza}

Prof. Jan Mazurkiewicz urodził się 12 lipca 1871 roku. Po uzyskaniu, w 1896 roku dyplomu lekarza, podjął studia podyplomowe w Grazu, a następnie w Paryżu. Pierwsze publikacje, ukazały się w 1900 roku w Grazu i wiązały się z badaniami nad podłożem anatomicznym i fizjologicznym życia psychicznego, co wynikało z przekonania, iż jest to jedyny słuszny kierunek warunkujący rozwój naukowy psychiatrii.

Znajomość piśmiennictwa oraz własna, oryginalna myśl kliniczna pozwoliły na opracowanie monografii m.in. fizjologicznej teorii uczuć i integracji wyższych czynności nerwowych. Kolejne publikacje tworzyły zręby tworzącej się teorii psychofizjologicznej, co skutkowało m.in. uzyskaniem w 1909 r. stopnia doktora habilitowanego, a w 10 lat później, tytułu profesora. Równolegle $\mathrm{z}$ pracą naukową, prof. J. Mazurkiewicz prowadził aktywną działalność lekarza praktyka. Organizował m.in. pracę w szpitalach w Kochanówce i Kobierzynie. Kierował ministerialnym Wydziałem Zdrowia. W latach 1909 - 1918 pracował na stanowisku docenta Uniwersytetu Jana Kazimierza we Lwowie. W styczniu 1919 roku, nadano doc. J. Mazurkiewiczowi tytuł profesora w krakowskim Uniwersytecie Jagiellońskim.Od października 1919 roku, aż do śmierci w 1947 roku, prof. J. Mazurkiewicz kierował Kliniką Psychiatrii Uniwersytetu Warszawskiego, piastując w macierzystej uczelni stanowiska m.in. dziekana a później rektora. W okresie okupacji był aktywnym wykładowcą na tajnych kursach dla lekarzy. Od 1924 roku - przez 23 lata pełnił funkcję prezesa Polskiego Towarzystwa Psychiatryczn ego $[1,2,3]$.

W czasie okupacji, prof. J. Mazurkiewicz ukończył pisanie 2-tomowego dzieła, poświęconego. , w tomie pierwszym: - ewolucji wyższych czynności psychicznych [4], zaś w tomie drugim: -procesowi odwrotnemu do ewolucji tj. odsłaniającej obraz kliniczny choroby - dyssolucji [5].

\section{Teoria psychofizjologiczna}

Angielski neurolog J.H. Jackson, nazywany przez J. Mazurkiewicza „ojcem neurologii światowej” przyjął, że podstawową funkcją układu nerwowego, który należy ujmować ewolucyjnie, jest gromadzenie i przekazywanie energii. Poszczególne etapy ewolucji układu nerwowego, H.J. Jackson rozpatrywał jako cztery dynamizmy piętrowe, stwierdzając że proces ewolucyjny przebiega od najprostszych funkcji automatycznych do zlokalizowanych w ośrodkach wyższych, funkcji dowolnych, bardziej złożonych ale jednocześnie słabiej zorganizowanych. Stąd też najwyższe ośrodki ewolucyjne są bardziej wrażliwe na uszkodzenia. Proces dyssolucyjny ( chorobowy), uszkadza częściowo piętro wyższe ( nigdy nie dochodzi do zniszczenia całego piętra ), co skutkuje objawami ujemnymi ( negatywnymi). Efektem tego procesu jest uwolnienie, ale już zmienionej chorobowo, aktywności piętra niższego, co przyjmuje postać symptomów dodatnich ( pozytywnych ). Profesor Mazurkiewicz, przeniósł ewolucyjno-dyssolucyjną koncepcję Jacksona na grunt psychiatrii, przyjmując cztery piętra rozwojowe aktywności psychicznej.

Stworzona przez prof. J. Mazurkiewicza teoria psychofizjologiczna, oparta na analizie rozwoju biologicznego podłoża wyższych czynności nerwowych (filogeneza)powtórzonego następnie błyskawicznie w okresie kilkunastu lat u człowieka (ontogeneza), tworzy naturalny, przyrodniczy model rozwoju najwyższych czynności psychicznych. Spojrzenie na chorobę jako następstwa, uszkodzenia wyższego piętra ewolucyjnego, skutkującego uwolnieniem się psychizmów niższych, przekształconych przez czynnik chorobotwórczy do formy objawów psychopatologicznych, sprawia, że teoria ta wg wielu psychiatrów stanowi również filozofię psychiatrii.Prof. Mazurkiewicz podał opis funkcji psychicznych, charakterystycznych dla poszczególny pięter ewolucyjnych. Pierwsze piętro to dominacja dziedziczonych instynktów (popę- 
dów, odruchów bezwarunkowych) sterujących funkcjami noworodka do 2-3 miesiąca życia. Od ok. 3 miesiąca do 2 roku życia rozwija się aktywność odruchowo-warunkowa, przejmująca kontrolę nad instynktami. Panujący w powojennej Polsce totalitaryzm, opierając się na zniekształconych zasadach teorii Pawłowa, ograniczał rozwój funkcji psychicznych człowieka do poziomu odruchów warunkowych. Teoria psychofizjologiczna wyróżnia dwa następne etapy rozwoju: okres aktywności intrapsychicznej, prelogicznej ( 3 - 7 rok życia) oraz trwający od ok. 7 roku do pełnoletności, okres formowania się, jak napisał twórca teorii: - „abstrakcyjnych procesów sprzężonej, intencjonalnej, przyczynowo - logicznej aktywności narządu czołowego". Funkcje najwyższego piętra ewolucyjnego u człowieka, uczeń a następnie współpracownik twórcy teorii, prof. Mieczysław Kaczyński, określił skrótem: „HOSS” co oznaczało, że piętro to pełni, w odniesieniu do pięter ewolucyjnie niższych, funkcje: - „hamujące, organizujące, scalające i sterujące [6,7]. Czynnik chorobowy uszkadza $\mathrm{w}$ pierwszej kolejności struktury najmłodsze filogenetycznie, a więc najbardziej zorganizowane ale jednocześnie najsłabsze, najmniej odporne.

\section{Typy dyssolucji}

Do zaburzeń psychicznych o charakterze dyssolucyjnym, prof. J. Mazurkiewicz zaliczył: - dyssolucjępsychonerwicową („wewnątrzpiętrową"), - dyssolucję powolną, prawdziwą (schizofrenia), i - dyssolucję prędką („deliryjną" - psychozy z zaburzeniami świadomości). Wg teorii psychofizjologicznej, choroby afektywne nie należą do zaburzeń dyssolucyjnych, gdyż ujawniająca się symptomatologia pięter niższych ma inny , „wtórny mechanizm” powstawania. Podobnie jest $\mathrm{z}$ „regresją dementywną", w której podłożem schorzenia jest „niszczenie substratu anatomicznego". Także inne psychozy, jak np. rozpoznawana dawniej parafrenia czy paranoja, nie nosiły cech dyssolucji piętrowej. Prof. J. Mazurkiewicz określał je mianem "ostrych lub przewlekłych psychoz prelogicznych".

Twórca teorii psychofizjologicznej zmarł 31 października 1947 roku.

\section{Rozwój teorii psychofizjologicznej w lubelskiej Klini- ce Psychiatrii}

Uczeń J. Mazurkiewicza, a następnie jego współpracownik w warszawskiej Klinice Psychiatrii, prof. M. Kaczyński, kontynuował myśl badawczą swojego nauczyciela. Po objęciu, w styczniu 1949 roku, kierownictwa lubelskiej Kliniki Psychiatrii, zajmował się głównie dyssolucją powolną ( prawdziwą) tzn. schizofrenią. Szczególnie ważny dla praktyki klinicznej, jest opis zmian charakterologicznych ujawniających się już we wczesnych stadiach choroby [8]. Badania późniejszego kierownika kliniki - prof. M. Masiaka, skutkowały opisem „równowagi dyssolucyjnej" charakteryzującej przebieg kliniczny schizofrenii prostej [9]. Efektem ponad 30-letniej ciągłej obserwacji grupy tych samych chorych na schizofrenię, podczas kolejnych hospitalizacji i remisji, było opisanie przez prof. J. Perzyńskiego, charakteryzującego schizofrenię paranoidalną, „skrzyżowania dyssolucyjnego” oraz pomocnych w diagnozie i prognozowaniu „kierunków dysolucji” i „mapy dyssolucyjnej” [10,11,12].

\section{Zakończenie}

Prof. M. Kaczyński, żegnając swego mistrza i podnosząc znaczenie koncepcji ewolucyjno-dyssolucyjnej czynności psychicznych - nazwanej „dziełem życia” - pisał: „Uważam, że gdziekolwiek wspominamy tego Uczonego, tam - z obowiązku właśnie naukowego, zawodowego i patriotycznego powinno być ono ukazywane. Poglądy bowiem dyssolucyjne, ułatwiają zrozumienie patogenezy symptomatologii psychiatrycznej na współczesnym poziomie wiedzy. Są to poglądy oryginalne, polskie, upoważniające do stwierdzenia, że istnieje polska psychiatria naukowa - która z uwagi na wysoki jej poziom - ma prawo wejścia na teren międzynarodowy"[13]. Wydaje się, że słowa te - chociaż upłynęło 70 lat - są nadal aktualne.

\section{Conflict of interest}

The author has declared no conflict of interest.

\section{References:}

1. Kaczyński M. Prof. Jan Mazurkiewicz. Pol.Tyg.Lek.1947.2.171176.

2. Nasierowski T. Jan Mazurkiewicz (1871-1947). Postępy Psychiatrii i Neurologii,1994,3,119-130.

3. Nasierowski T. Listy do przyjaciela. Psychiatria polska początku XX wieku w listach Jana Mazurkiewicza do Witolda Chodźki. Postępy Psychiatrii i Neurologii,2002, 11,391-405.

4. Mazurkiewicz J. Wstęp do psychofizjologii normalnej. Ewolucja aktywności korowo-psychicznej. Warszawa. PZWL. Tom I.1950.

5. Mazurkiewicz J. Wstęp do psychofizjologii normalnej. Dyssolucja aktywności korowo-psychicznej. Warszawa. PZWL. Tom II.1958.

6. Kaczyński M. Wykłady dla lekarzy na kursie dot. diagnozy wczesnej schizofrenii. Klinika Psychiatrii Akademii Medycznej w Lublinie.1968.

7. Dobosz A., Pankalla A. Jana Mazurkiewicza mitocentryczna koncepcja osobowości, SensusHistoriae. Vol.XVIII ( 2015/1), 111-127.

8. Kaczyński M. O zmianach charakterologicznych we wczesnej schizofrenii. Neurol. Neurochir. Pol. 1962.XII.4.545-549.

9. Masiak M. Badania kliniczne i eksperymentalne nad odrębnością obrazu klinicznego i podłoża biologicznego niektórych typów schizofrenii. Praca habilitacyjna. Akademia Medyczna.Lublin,1976.

10. Perzyński J. Skrzyżowanie dyssolucyjne jako psychofizjologiczny model przebiegu schizofrenii paranoidalnej. Badania nad schizofrenią, Lublin,2005,VI,6,33-39. 
11. Perzyński J. Typy i kierunki dysolucji. Badania nad schizofrenią. Lublin, 2007,VIII,8,13-20.

12. Perzyński J. Mapa dyssolucyjna. Badania nad schizofrenią, Lublin, 2008,IX,9,18-20.

13. Kaczyński M. Prof. Jan Mazurkiewicz, Polski Tygodnik Lekarski, 1947,1,171-176.

\section{Correspondence address}

Aneta Perzyńska - Starkiewicz

II Klinika Psychiatrii i Rehabilitacji Psychiatrycznej

Uniwersytet Medyczny w Lublinie

20-439 Lublin, Głuska 1

Otrzymano: 10.10 .2017

Zrecenzowano:31.10.2017,30.11.2017

Przyjęto do druku:07.12.2017 